\title{
Comments on the book of Tereza Matějčková Gibt es eine Welt in Hegels Phänomenologie des Ge- istes? / "Is there a world in Hegel's Phenomenology of Spirit?", Tübingen: Mohr Siebeck 2018
}

\author{
Pirmin Stekeler-Weithofer \\ Institute of Philosophy \\ University of Leipzig \\ Beethovenstraße 15, 04107 Leipzig \\ stekeler@uni-leipzig.de
}

Tereza Matějčková's book presents a highly interesting phenomenological reading of Hegel's early masterpiece. The result is a proposal to take the title seriously - such that we can see the book as the earliest introduction into the methods and topics of philosophical phenomenology, despite the fact that Husserl himself, in contrast to Heidegger, did not seem to see the narrow relation. I especially value Tereza Matějčková's very deep understanding of the dialectical humour and irony of Hegel's writings. However, I understand the Phenomenology of Spirit in a somehow more radical way as a most general 'logic' of self-consciousness. It shows how referring to myself is referring to the world and vice versa, despite the fact that the word 'world' does not play a prominent role in Hegel's text. Some disagreements result over Hegel's wide use of metaphors and analogies in his structural analysis of personal self-relations, for example in his reconstruction and critique of the age-old (in fact Platonic) image of a fight between a thinking soul as master and a system of immediate bodily desires as slave. We cannot get rid of inclinations and appetites, and we cannot retreat, as the Stoics had thought, into pure thinking. In other words, there is no fight 'for recognition' between different individuals in Hegel's book, but in the end an answer to a classical theodicy saying that the world, as it is, is the best one we have because there is only one world.

Key Words: being, mundicy, phenomenology, consciousness, master-slavedialectics 
1. The title "Is there a world in Hegel's Phenomenology of Spirit" of Tereza Matějčková's book (in the following: TM) surprises the reader in more than one aspect. The first has to do with the well-known fact that Hegel does not use the word "world" in a terminological way. The concept of the world (or of a world like my world or our world) does not stand in the focus of Hegel's Phenomenology, as TM says herself on p. 10, referring also to texts on this topic by Hermann Braun und Christian Bermes. We could, however, immediately add that virtually no expression in Hegel's philosophical reflections is terminological in the traditional sense of defining an intended local usage of the expression explicitly, for example by listing necessary and sufficient specific differences. Not even the ominous expressions "an sich" and "für sich" (resp. "in itself" and "for itself") are in this sense terminological. Instead, Hegel uses already well-established expressions in the philosophically developed European languages like Plato's "kath'auto", Latin “per se”, English "as such" or "in itself" in order to mark that some proposition has to be read in a generic way, as I would like to say. Talking about the person or the state an sich thus refers to a type or a whole form of being. Something is true "an sich" if it is true "in principle". The world "an sich" is what we say about the world in such a generic or principled way. Something is "for itself" insofar as it stands in a relation to itself - just as the Latin word "pro" stands in general for a relation. Similar remarks could help to demystify Hegel's love for a word like "Aufhebung" ("sublation”). Hegel uses it without definition in order to differentiate, elucidate and comment upon misleading and good aspects in the conceptual usages of words in ordinary, scientific, and philosophical reflections.

Moreover, in contrast to a Historisches Wörterbuch der Philosophie, Hegel is not so much interested in a history of words and their first appearances, as we could find them today everywhere by using digital methods, but in the development of concepts and ideas. Concepts are, as such, (conceived as) invariant to translations into other languages of course in relation to the contexts that we have to translate as well, and the relevant types of situations that we have to know implicitly. As a result, we must be able to represent or paraphrase a concept by many different but equivalent words (even in our own language) and evaluate 
how the replacements are suited to the contexts - thus determining the topic and focus of the relevant distinctions and inferences.

2. The main topic or theme of Hegel's Phenomenology is (self-)consciousness. Hegel himself clearly says that consciousness has to be taken not as something inner. It is not "in" the head, heart, or body. Being "in" the mind or soul is also just a metaphor. The philosophical question is how the inner-like human consciousness really appears in outer behaviour, in (repeated forms of) concrete action and (verbalized) thinking (cf. pp. 33f) - and how we have to distinguish it from animal "consciousness", viz. vigilance, awareness, and attention. Desire is, in this context, a first step to self-consciousness, namely as self-awareness of proto-intentions. TM therefore articulates the leading question of her book in this way (p. 7): What does it mean that "thought as objective thought" is "the inner of the world"? In fact, it is Hegel's most important insight that the word "inner" usually stands for conceptual content and therefore for semantical rather than for psychological, (neuro-)physiological or other "natural" structures or processes "in the head" or for "metaphysical" theories of "spiritualism". Until today, many philosophers still confuse idealism with such a spiritualism.

3. At first sight, we can take the word "world" as a rather harmless (but somehow arm-waving, in this sense "sweeping") title just for everything. As such, it belongs to the field of speculative totality-words that refer like "being" to a whole of "all there is" and, as such, to a general aspect or moment of objective empirical reality (cf. p. 20f). If we are interested in the corresponding concepts of this field like reality or existence we have to consult the second book of Hegel's Science of Logic. There, we find under the heading "Logic of Essences" (Logik des Wesens) an analysis of even more problematic speculative and holistic words like nature and real reality ("Wirklichkeit"), objectivity, truth and appearances (of objects and matters, events and processes).

Hegel's basic insight here is that talking about what is real or objective always belongs to a logic of reflection. What we talk about in such a way can never be well-understood if we assume an immediate correspondence 
to a given "world" or "nature", especially if such a world is a Ding an sich - in Kant's confusing and confused sense. Like traditional metaphysics, Kant posits such "things an sich" somehow behind the domain (Bereich), realm (Reich) or world (Welt) of appearances, i.e. of empirical objects and events here or there, now or then. If we notice the subject-related and perspectival meaning of all such local and temporal demonstratives or indexical (respectively anaphoric) pronouns, it is clear why it is just a formal truism, an analytic truth, that a thing an sich cannot be perceived. However, this does not sufficiently answer the question of what we talk about when we talk about a thing or world an sich. Hegel's answer is, in my reconstruction, that we talk about generic generalities. Such generalities are canonized features of our concepts and theories - by which we explain particular singularities in the empirical world. According to Hegel, Kant did not know or understand these central facts of "the concept", referring to the system of concepts as we always already transcendentally presuppose it in our acts of understanding. For Hegel, the "true nature" or "essence" of anything is thus determined by a good enough (respectively better or deeper) understanding of its normal or canonical appearances, in contrast to a merely accidental, subjective or superficial access to it.

Before I continue, things get clearer and shorter if I confront TM's analysis with my own reading. Let me mention first our total agreement that we must read Hegel in comparison with what Plato says about the concept (eidos) and participation (methexis) and the unity and plurality of things (especially in the dialogues Parmenides and Sophistes, cf. pp. $39 \mathrm{ff}$ and 56ff). However, I would be more radical than TM and claim that Hegel is hitherto the only logician who has really learned the lesson of Kant's insight into the transcendental constitution of objects to which we can refer in thought and apperception. From a modern point of view, any such constitution is a version of "abstraction".

As its analysis in the logic of essences shows, already our talk about differences ("in the world") is reflective and "abstract" in the following sense: It turns the "subject" (or better: referent) of subjective differentiations ("negations" in speech acts, behavioural attitudes and actions) into an "object of reflection". It presupposes a joint practice, in 
which we evaluate whether the relevant distinctions are made properly. I. e. differences, properties and all kinds of entities are posited (gesetzt) as referents of reflective names - which can result from a nominalization of predicates, like "justice" comes from "just" and "truth" from "true". In talking about object-related differences, we presuppose identityconditions defined by equivalent replacements of different appearances, presentations or representations "of the same difference".

4. In the same way, we have to understand, for example, our talk about causes, things or matters. A cause is already an "abstract" object or process that presupposes an evaluated success of causal explanations. A thing is defined in its identity on the ground of an equivalence relation between different presentations and representations "of it", as we say in retrospect. The "being for itself" of an object, i.e. its identity as a system of self-relations, is defined by a generic equality ("in itself", "as such") and a presupposed evaluation of equivalence between various of "its" appearances, as we say in hindsight. TM talks about this by using the old form of a "dialectic of unity and plurality" of things or objects (p. 37). An appearance is therefore a subjective access to the object, as we say a posteriori, i.e. after we have already presupposed the logical constitutions of the identity of the object or entity, to which we refer.

Being and not-being become symmetrical just because any determination presupposes "its" opposite or contrast in a generic domain or genus, in which we make differentiations. They are, however, only in this sense "identical". This leads us to the following reading of Hegel's mystifying verkehrte Welt as a "world inside out": we posit (verbally) ideas as real causes of real appearances and talk as if such mere entities of thought or of mathematical models could "really produce" anything in the real, empirical, world (cf. e.g. p. 60 and chapter 4).

5. TM says that the absolute "finds a hiding place in the human subject". By this, she tries to represent Hegel's insight that (only) performances are absolute, i.e. not-relative to the fulfilment of conceptual satisfaction conditions: Acting so makes it so. According to my reading, this deep insight defines the core of Hegel's “objective”, i.e. non-subjective, and 
"absolute" idealism. TM articulates this fact in some weaker ways (p. 93): "The essence of man lies in the performance". In the end, the totality of empirical processes "performed by the world", so to speak, is the absolute world, talked about from a speculative or imagined "divine" standpoint outside the world.

Theology is in its talk of God an early or logically still juvenile version of speculative philosophy, just as modern physicalism or materialism is. The latter talks about an ideal physicist that knows about the world's mechanisms. In other words, the world in theology and the world in physicalism are reduced to the content of the knowledge of some counterfactual person-like ideal subjects. The truth of these images lies in the fact that in talking about the world we always already make use of counterfactual holistic ideas in a grand scale (p. 27, 29f). When we thus read Hegel as a logician, we see clearly that he encounters the problem that abstraction and entity-constitution as well as all "absolute" notions of an unconditioned whole (for example of the world of all being and all performances or processes in the world) are obviously difficult to grasp. When we do not see this, the very ground of Hegel's idealism is missed.

TM's reading is, so to speak, that of a phenomenologist. In fact, TM stands somehow in the tradition of Jan Patočka and Czech Hegelians like Kosík (et alii). This explains why she refers sometimes also to the works of Martin Heidegger, Hannah Arendt or Eugen Fink (cf. e.g. p. 17, 22, 46 et passim). If we understand clearly enough what phenomenology is, we can say that Hegel was indeed a phenomenologist avant la lettre. In this evaluation, I totally agree.

In contrast to philosophical empiricism, phenomenology tries to put problematic presuppositions into brackets. Empiricism, instead, either starts with sensations, sense data or subjective qualia - which are no entities at all because of the lack of well-defined identities - or with a world of bodily things as if these were immediately given, as Thomas Hobbes suggests in his atomistic physicalism, followed by John Locke or even W.V.O. Quine. Edmund Husserl's expression for this bracketing of dogmatic and uncritical prejudices is the Greek word "epochē". In the case of his Phenomenology of Spirit, Hegel puts all "inner" contents and "outer" objects in talking and thinking, perception and intuition 
also into such a quarantine. The idea is to reflect explicitly on implicitly presupposed equivalence relations that define content and reference (Frege's Sinn and Bedeutung) in perceptions and thinking. To do this, phenomenological philosophy has to show, display and comment upon what we really (have to) do when we (try to) perform some intelligent action with (self-)consciousness.

Such a phenomenology is, as Hegel famously says, self-consuming scepticism in the sense that the wrong judgements of philosophical empiricism from Sextus to Descartes, Hume (and even Kant) disappear or are sublated. One of these claims or prejudices says that appearances cannot be inconsistent, contradictory, but only assertions or propositions. Hegel sees, instead, that even the merely enactive perception of animals can be wrong, incoherent, or "counterproductive". This holds in view of its empirical role for the animal's actual behaviour, which can stand in contrast to a principled or generic, species-specific, aim of wellbeing. This tension reappears on a higher level in human apperception, i.e. for perception accompanied by judgements about what is perceived and what has to be done in consequence: Human access to the world is always-already conceptually formed. There is no concept-free "intuition" (Anschauung) as Kant suggests, not to speak of Locke's and Hume's naked sensations.

6. In the end, the main question of the book is not so much if there is a world in Hegel's Phenomenology at all. The title turns into the question of how to differentiate between different "concepts of the world", i.e. into the question: What is the difference between good and bad ways of talking about the world, and between showing good or bad attitudes to the world? By focussing on these questions, which only at first sight seem marginal in the Phenomenology, the book presents a new interpretation - or rather commentary - of major (not all) parts of the book.

Interestingly, TM pledges at the same time for a robust reading of Hegel - warning against the danger of losing or destroying down-toearth understandings of our concepts and the world at large. In this, TM shares with Hegel a most important attitude. As a result, she also favours what we could label „Hegelian Irony or Humour“, as it can be placed 
somehow between the "Socratic Irony” of Plato and „Romantic Irony“. This is so despite the fact that Hegel vehemently attacks the irony of Friedrich Schlegel as utterly subjective and irresponsible, but somehow follows Solger's mediation. In fact, Hegel's own dialectic is informed by the dialogical idea of the "symphilosophy" of the Romantics (according to Novalis or perhaps also to Schlegel's Jena lectures) and their insight into the metaphorical, metonymic and gnomic forms of expression in philosophical reflections (cf. chapter 11).

7. Wondering about the world had been a motif for doing science ever since it started under the label "philosophia", in German (following C. Wolff): Weltweisheit. Modern philosophy starts with the question of what we know about the outer world not because there would be any reasonable doubt about its existence but because of the methodical order in the very concept of knowledge. Idealism starts, as it were, with the insight than any knowledge claim presupposes an understanding of its differential and inferential content. It presupposes thinking and (self-)consciousness in the sense of our faculty to control the fulfilment conditions of one's own beliefs or knowledge claims.

It might already be too much to talk of "Kant's retreat into subjectivism", as TM does. The fact, that no one can "get out of his head" (or skin) means this: No one can watch himself from an outside perspective - even though we may use mirrors and reflect on our thinking by talking about its outer and inner, phenomenal and conceptual forms.

For a phenomenological reflection on consciousness and selfconsciousness as knowledge and self-knowledge in the widest sense, we have to start with appearances "for us" (cf. p. 26). The final task is, as $\mathrm{TM}$ also says, to be at home in the world, i.e. to reconcile my world (see chapter 6) with the world (and not to identify both as the young Wittgenstein still does under the influence of Schopenhauer). In any case, we should refrain from a "constructivist" reading of Kant's (and Hegel's) analysis of the "constitution" of our joint reference to finite objects in the world (cf. p. 35). Constructivism is subjective or formalist idealism - and vice versa. Berkeley, Kant, and Fichte can be gathered under these labels. 
TM is also right to stress Jacobi's influence on the "Romantic" enterprise to act against the prosaic nihilism in Hobbes's atomism and even still in Kant's theoretical Newtonianism. At first sight, Hegel somehow wavers between an allegedly robust subjectivity in Greek life and modern naturalism; but in the end, Hegel rather sees that postChristian modernity develops a deeper understanding of subjectivity in its logical priority to any "object-related" belief. A retreat from the (natural and personal) world (of Bildung as self-formation) into one's own subjectivity is a kind if re-animalization of oneself.

8. The modern attitude to the world starts, indeed, with the Christian insight that we have to recognize the brute fact that many "negative" things happen in the world against our wish and will. We have to cope with the radical limits of knowledge and power. There is no (good) life without suffering; hope for Nirvana is just waiting for death in apathy.

We should therefore also radicalize TM's analysis of Oedipus Rex and Antigone by saying that personal responsibility presupposes much deeper and wider self-control of accuracy (in the sense of Bernard Williams' Truth and Truthfulness) ${ }^{1}$ than the Greeks could have had. They were not yet clear enough in removing the unforeseeable consequences or side-effects of the deed from the responsibilities of the actor.

TM's parallel analysis of conflicts in the world of politics is quite interesting, especially in view of how these struggles (or even wars) may lead in the end to the terror of an assumed majority leader like Robespierre (p. 256f). Hannah Arendt agrees with Hegel that here political murder becomes possible "without any interest for the person". I.e. the personal subject and its absolute worth do not count at all. Any politics of this form is utterly inhuman. TM connects this inhumanity with Creon in his sentence of Antigone (cf. also pp. 220ff) via the following considerations: The death of any individual human being is not just a matter of nature. It is reflected and made conscious in a Totenkult - reminding us that the person as such had been (and still is) a member of our human community (p. 109 and p. 257). Any regime that does not honour the dead - as Creon and the Nazis did - thus make their deep inhumanity manifest.

1 Williams (2002). 
9. On p. 82, TM explicitly disagrees with my interpretation of Desire (better: Animal Appetite, Begierde) and Labour (Arbeit), and of the passages on Master and Slave, Stoicism and Skepticism in the chapter on the notion of self-consciousness. I read Hegel's talk about "work" indeed not as referring to some special case of participating in a modern division of "labour" but to the much more general case of an action that presupposes some overruling of inclinations or merely enactive desire. It does so by thinking, planning, and self-conscious evaluation of its outcome as fulfilling (or not satisfying) certain conditions. I propose to read the passages about a fight for life and death and Hegel's talk about death as the ultimate master as a mere side-remark about the urbild of a metaphor. Hegel says here, indeed, that serfdom is always free in the sense that it is preferred to death. This is so because anybody can, at least in principle, kill herself and others or let herself be killed, as Hegel himself says at some places. According to my reading, however, Hegel tries to make clear how the metaphor or allegorical analogy fits into the frame of an "intra-personal fight" between inclination and duty, i.e. between animal desire and personal intention, between mere behavioural conduct and planned, self-conscious, action ("labour").

10. A stoic is not, as TM says, originally a slave. Stoicism is rather similar to Romantic irony that fancies itself as the master of the world, as if all things could be detached from us by a retreat into free thinking. The stoic thus proposes a kind of higher will and thought, including higher duties, that do not care for inclinations, desires and other "worldly things". There is some hidden allusion to Kant's latent stoicism here - and to his wrong contrast between "natural" or "animal" inclination and "personal" duty; bodily motifs and self-determining, free will.

In a much more radical way than in stoicism - which in a sense follows Socrates and his philosophical teaching of how to die - the life of Christ shows that negativity, i.e. suffering and pain, are part of our life and of the world as such. It is therefore wrong to think that avoidance of pains and maximizing pleasures are the main goals of a good life. Even public contempt and condemnation are not at all the last words about a good or even perfect life as a personal subject. TM rightly shows this on pp. 289 
ff, esp. 292ff. Death loses its sting if we learn to distinguish between the person as manifested personhood, traditionally addressed by the word "psychē" as a whole form, and the individual subject right now or in its finite parts.

An "empirical sceptic" (like Sextus Empiricus or Hume) is, in contrast to a stoic, always in danger of returning to the animal kingdom, using all his understanding and rationality only for leading a painless or lustful life and denying all deeper interest in science and philosophy, personhood and mankind. This danger comes from an all too shallow pragmatism. The unhappy consciousness - which is, in fact, a widespread selfmisunderstanding of Christianity - still works with the superstitious idea of a life after death and some rewards for a "good" life in paradise. As a result, the actual world turns into a vale of tears. Hegel tries to show that and why such an understanding of the "higher" and "inner" attitude of a thinking soul (alias person) still does not solve the tension between stoicism and scepticism (respectively Kantianism and utilitarian pragmatism).

11. In the passages on the unhappy consciousness, Hegel starts (or rather continues, as it were) his (and Fichte's) program of the secularization (Verweltlichung) of all parts of Christian theology and religion. This is done in such a way that Ludwig Feuerbach, Karl Marx and Friedrich Nietzsche can (and must) be seen as epigones and followers, despite their (confused) criticism of German Idealism, as TM also sees (pp. 230ff). Such a secularization means bringing talk of God and Heaven, the Soul and Eternity (Infinity) down to earth (cf. also pp. 289ff) - according to the main program of the Phenomenology, to make the world into our home, which is, in a sense, the deepest insight of TM.

The "finitude of the world" (p. 150) does not mean, however, that the world is finite. It means that all real things, matters and processes in the world are finite (in space and time). The "infinity of the I" (p. 150) refers to the time-generality of the transcendental subject, i.e. the generic I which is a generic We, just as the form or spirit of a personal institution. 
12. Under the title "Theatrum mundi" (p. 217) and in appreciation of Hegel's discussion of seemingly non-philosophical literature, from Sophocles to Diderot and Goethe's Faust, TM argues convincingly for bringing the grand narratives of world literature into closer connection to philosophical thinking and reflection about the world. Here, the possible worlds of fiction are only conceptual constructions as such, an sich, representing possible types of being or life in contrast to empirical reality manifested in-and-for-itself.

According to my reading, Hegel's secularization ends in a secularized theodicy, a defence of the world as it is against depressive critics who compare its faults with fictional utopias and other proposed meliorizations. I.e. theodicy is understood as a kind of "mundicy", a criticism of the one and only world there is. Even though TM does not seem to share this view on the apotheosis of Hegel's Phenomenology, her book is really a necessary work, a must read to anybody interested in Hegel's masterpiece - and in the holistic concepts of my world, our world, and the world.

\title{
References
}

Matějčková, T. (2018): Gibt es eine Welt in Hegels Phänomenologie des Geistes? Mohr Siebeck, Tübingen.

Williams, B. (2002): Truth and Truthfulness: An Essay in Genealogy. Oxford Princeton University Press, Princeton.

\begin{abstract}
Abstrakt
Komentáře ke knize Terezy Matějčkové Gibt es eine Welt in Hegels Phänomenologie des Geistes? / "Is there a world in Hegel's Phenomenology of Spirit?", Tübingen: Mohr Siebeck 2018

Kniha Terezy Matějčkové představuje velice zajímavé fenomenologické čtení Hegelova raného mistrovského díla. Výsledkem je návrh vzít název tohoto díla vážně - takto můžeme chápat knihu jako nejranějšś úvod do metod a témat filosofické fenomenologie, a to navzdory skutečnosti, že sám Husserl, jak se zdá, zde narozdíl od Heideggera neviděl př́mý vztah. Zvláště oceňuji Terezino velmi hluboké
\end{abstract}


chápání dialektického humoru a ironie Hegelova díla. Nicméně já chápu Fenomenologii ducha poněkud radikálněji, totiž jako nejobecnější ,logiku' sebe-vědomí. Navzdory tomu, že slovo „svět“ nehraje v Hegelově textu význačnou roli, kniha ukazuje, jakým způsobem referování o sobě samém znamená referování o světě a naopak. Některé neshody pramení z pojetí Hegelova širokého užití metafor a analogií ve strukturálních analýzách osobního vztahu k sobě samému, např. v jeho rekonstrukci a kritice prastarého (vskutku platónského) výjevu boje mezi myslící duší jakožto pánem a systémem bezprostředních tělesných tužeb jakožto rabem. Nemůžeme se zbavit náchylností a tužeb, ani se nemůžeme stáhnout k čistému myšlení, jak si mysleli stoici. Jinými slovy, v Hegelově knize nejde o boj ,o uznání mezi různými jedinci, ale v posledku o odpověd’ na klasickou teodiceu, která ř́ká, že svět, tak jak je, je ten nejlepší, jaký máme, protože je pouze jeden jediný.

Klíčová slova: bytí, mundicea, fenomenologie, vědomí, dialektika-pána-a-raba

Stekeler-Weithofer, P. (2020): „Comments on the book of Tereza Matějčková Gibt es eine Welt in Hegels Phänomenologie des Geistes? / "Is there a world in Hegel's Phenomenology of Spirit?”, Tübingen: Mohr Siebeck 2018.“ Filosofie dnes 12 (1): 20-32. Dostupné z www.filosofiednes.ff.uhk.cz 